\title{
SCIENTIFIC ASPECTS OF WATER MANAGEMENT IMPROVEMENT IN UKRAINE
}

\section{Hranovska L. M.}

\section{INTRODUCTION}

The water-economy and melìorative complex is one of the most powerful segments of the economy in Ukraine and on the whole, and in Kherson region in particular. It is represented by a significant number of water economy and melioration facilities that are designed to meet the needs of the population and sectors of the economy in qualitative water and, creation of the optimal conditions for crops cultivation and rational use of reclaimed lands in the context of food security of Ukraine.

Attraction of large volumes of water resources of southern region into economic exchange to ensure the development of branches of economy: industry, recreation, agriculture, including irrigation melioration, has led to a change in the hydrological regime in the water-catching areas, violation of natural balance, a sharp decrease in the quality of water-resource potential, the superiority of degradation processes over self-healing and self-purifying capacities of water ecosystems. At present, there is a great need to solve the problems of integrated development of water economy as a holistic ecological and economic system of the region taking into account the needs for insurance of protection and rational use of all natural resources, modern changes in environmental management and social development strategy of the region.

Today, there is almost no area on the globe, wherever there was no manifestation of direct or indirect effect of anthropogenic change on the natural landscape, including hydrosphere. Hydrosphere contains about 1.6 billion $\mathrm{km}^{3}$ of free resources, including 1.37 billion $\mathrm{km}^{3}$ of the oceans share. On the continents - 90 million $\mathrm{km}^{3}, 60$ million $\mathrm{km}^{3}$ of them - groundwater (almost all are saline), 27 million $\mathrm{km}^{3}$ - the glaciers of Antarctica, Arctic and mountains. A useful volume of available fresh water concentrated in the rivers, lakes, ponds, reservoirs, subsurface waters to the depth of $1 \mathrm{~km}$ is 3 million $\mathrm{km}^{3}$. This is a relatively small supply of fresh water, but due to recycling, it is constantly replenished and solves the problem of water supply of the planet. However, unfortunately, the condition of full preservation of the quality of water resources is not provided at all. Even the most advanced

${ }^{1}$ Сербіна Р.А. Екологічне страхування меліорованих земель - метод компенсації імовірності виникнення еколого-економічних ризиків. Економіка. Рівне, 2011. С. 40-46. 
purification technologies, including biological one, do not provide complete and qualitative purification of wastewater. All dissolved inorganic substances and about $10 \%$ of organic pollutants remain in the purified wastewater. The World watershed balance states that about $2200 \mathrm{~km}^{3}$ of water per year is used for all directions of water use. Dissolving wastewater consumed $20 \%$ of freshwater resources, and $1 \mathrm{~km}^{3}$ of treated sewage contaminates $10 \mathrm{~km}^{3}$ of the river water, untreated ones $-3-5$ times more ${ }^{2}$.

According to the state Water Resources Agency of Ukraine, the volume of water resources of Ukraine, which consists of surface and groundwater, is $73.1 \mathrm{~km}^{3}$ per year, and the volume of an annual use is $19-24 \mathrm{~km}^{3}$. Almost one third of the total reserve of water resources is annually used by the industrial complex of Ukraine and in the form of waste waters, purified, insufficiently purified and non-purified, it is dropped into water sources. Thus, the amount of fresh water in a voluminous expression does not decrease, but its quality worsens dramatically, and the consequence of this is an increase in the deficit of qualitative fresh water resources. The provided examples of the development of anthropogenic processes indicate the presence of real ecological risk, which is formed both at the regional and at the global level under the poorly balanced further development of the economic and industrial complex of the region.

The process of management of the water and meliorative complex of southern region as a complex ecological-economic system provides the complex systematic approach to solving all the problems of development of each subsystem and the ecological and economic system, ensuring the water use and preservation of the environment. The development of each of the subsystems and individual industries have different, and sometimes quite opposite requirements for water resources, which leads to conflicts of interest in the field of water use of the region. While solving these conflicts, water users' attention focuses on the use of water resources and conditions, and the issue of protection and reconstruction of resources relies on state power structures, or even is inherited by further generations ${ }^{3}$.

Complexity of management of the catchment area of the region provides for the solution of questions concerning the use, protection and restoration of water resources of the country. In this connection, there is an indisputable need to intensify the process of ecologization of water activities in the system of the watershed and meliorative complex, as well as public relations on ensuring the sustainability and balance of the development of a complex water ecological and economic system of the region.

\footnotetext{
${ }^{2}$ Ромащенко М.I. Концептуальні засади відновлення зрошення у Південному регіоні України. Меліорація і водне господарство. Київ, 2013. Вип. 100. С. 7-17.

${ }^{3}$ Галушкіна Т.П., Грановська Л.М. Еколого-збалансовані пріоритети розвитку територій: концептуальні засади та організаційний механізм. Одеса: IPРЕЕП, 2009. 372 с.
} 
To restore and expand the irrigation areas according to the approved by the Cabinet of Ministers of Ukraine in 2019, Irrigation and drainage strategy in Ukraine for the period until $2030^{4}$, and ensuring the ecological and sustainable development of water systems it is necessary to solve a number of environmental and meliorative problems, first of all, it is necessary to introduce the systems of environmental management in the water economy of Ukraine, conduct ecological audit and define modern technological facilities of irrigation systems and hydrotechnical constructions, improve the system of ecological monitoring in order to assess ecological and melìorative conditions of agricultural land, provide integrated water management, adapt the work of irrigation systems and regimes of irrigation of crops to change in climate, improve the quality and fertility of irrigated soils, introduce innovative methods of irrigation, improve the system of land ownership and land use, as well as the system of institutional support for effective management of water resources. All these will create conditions for the sustainable socio-economic development of the agricultural sector in the zone of irrigation and rural areas. The issues of renewal and expansion of irrigation areas in southern region of Ukraine remain relevant, and the issues of combination of the current ecological conditions of the irrigated land by the directions of legislation improvement and the introduction of environmental management both in the water management system at the national level and at the regional and local levels remain unresolved.

\section{Theoretical justification of principles and trends in introduction of environmental management and audit in the water economy sector of Ukraine}

The first definition of "environmental management" was proclaimed in "Agenda for the XXI century", adopted in Rio de Janeiro in 1992, which emphasized that "environmental management is attributed to key dominant sustainable development and at the same time to higher priorities of economic activity and entrepreneurship".

For the realities of Ukraine it is necessary to specify this concept, taking into account that without transformation of the general system of management of sectors of the economic and industrial complex, it is impossible to speak about the reformation of the management system at the local level, i.e. at the level of the organizations. Such a quotation is defined by the motivation and incentives to implement the system of environmental management. We are talking about the preparation of the appropriate basic

\footnotetext{
${ }^{4}$ Про схвалення Стратегії розвитку аграрного сектору економіки на період до 2020 року. Кабінет Міністрів України; Розпорядження. Стратегія від 17.10.2013 № 806-р. Верховна рада.
} 
basis (legislative, regulatory, economic), which would ensure the development of environmental management in Ukraine. At present, it can be argued that the systems of motivation incentives for the introduction of environmental management and auditing in Ukraine and elsewhere are somewhat different. For the West - it is a conscious desire to improve the image and enter the market leaders, which gives additional chances to obtain a guarantee of the bank for credit, and for Ukraine - the desire of the enterprise to get the system of privileges in the legislative order (in taxation, crediting, social programs). This is explained by the fact that for Ukrainian environmental management there is not yet formed that benevolent macro-environment that would have prompted them to independently seek an effective management decisions on ecologiztion of the system of existing management.

Thus, it can be claimed that the most important factor of reforming the existing water management system at the current stage is the creation of organizational bases and corresponding motivation incentives to introduce in the water industry of innovative management with the elements of environmental management. Today, however, this direction is still insufficient, whereas the strategic goal of Ukraine's development is transformation of its natural resource potential into the main resistance of economic growth for sustainable development from the point of view of the global community ${ }^{5}$. Environmental management should be regarded as a qualitatively new ideology of management of water economy activities in the market conditions, which is based on the following principles:

- Importance of the role of water industry branch for the development of the country's economy. Water industry provides sectors of the economy, including agriculture and the population with water for drinking needs, irrigation and communal needs. All these create jobs, allows the development of the economy of regions and the country on the whole. The strategy of irrigation and drainage in Ukraine for the period until 2030, which is implemented in the water industry, will solve the priority tasks of the Strategy of agriculture and rural areas development for the period until $2020^{6}$;

- Complexity of the development of the economy, settlements and rural areas. Complex principle will allow to send investment resources in the innovative development of the water industry, agriculture and rural areas; will ensure the creation of a legislative institutional environment for the formation and development of decentralized and environmentally balanced enterprises and associations in the agricultural sector of the economy in the zone

\footnotetext{
${ }^{5}$ Програма економічних реформ Президента «Заможне суспільство, конкурентоспроможна економіка, ефективна держава». http://www.president.gov.ua/docs/Programa reform FINAL_1.pdf.

${ }^{6}$ Стратегія зрошення та дренажу в Україні на період до 2030 року. https//zakon.rada.gov.ua/ laws/688-2019-p/print.
} 
of irrigation through the introduction of state-private partnerships in the water economy ${ }^{7}$;

- Complex management of water resources. Agriculture in southern region of Ukraine is a powerful user of water resources, but the complex management of water resources should provide for conflict-free supply with water resources of all the water users: agriculture, industry, municipal economy, population and recreation;

- Separation of the water management functions and water economy infrastructure. Today, these two functions of water management are carried out by the state Water Resources Agency of Ukraine that sometimes leads to contradictory actions and decisions. Hydrotechnical constructions and water facilities are built for the needs of industries and have the most regional significance (anti-flood protection, drinking water supply, land reclamation, groundwater level control), so the management of these objects should be decentralized and not combined with the function of water resources control. Water users have to be involved into water management at the level of the amelioration system;

- Introduction of state-private partnerships in water management. This principle involves the transfer of management of irrigation and drainage systems to a lower level, that is, the unification of water users (associations, etc.). On the basis of researches of the Sumy school scientists it was proved that state-private partnership in the field of natural resources can be defined as legally designed for a certain period mutually beneficial cooperation of bodies and organizations of State power and business-entrepreneurial structures (environmental) infrastructure. Such a partnership provides for the allocation of responsibility, risk and results between partners with the purpose of the most effective implementation of environmental projects that have important state, regional and social values. Therefore, the system of state-private partnerships in the water sector can be stated as a mutually beneficial cooperation between the bodies of the state control system with private ownership of engineering infrastructure. The management of main canals and pipelines and water economy objects of interregional significance is carried out by regional state operators and the management of amelioration system objects must be carried out by water users, which are united in an organization or association of water users.

The law of Ukraine "on state-private partnership" (2010) defined the organizational and legal principles of interaction of State partners with private partners and the basic principle of a state-private partnership on a contractual basis, defined the spheres and applications of state-private partnerships

7 Закон України «Про державно-приватне партнерство». Відомості Верховної Ради України (ВВР), 2010. № 40. Ст. 524. 
including the water industry, and defined the forms of a state-private partnership and the types of contracts, which could be concluded between the State and private partners (concession, cooperation and others);

- Reconstruction and modernization of water facilities with the aim of their ecological safety and ecological reliability. To perform this principle, it is necessary to introduce a system of ecological audit of the entire infrastructure of the water industry and irrigated agricultural lands, because the base for the development of the stages of reconstruction and expansion of irrigation areas and the construction of melioration systems are to be the results of ecological audit.

- Environmental audit as a basis for the reconstruction and development of the water industry. Environmental audit is one of the most important tools of the environmental management in the field of environmental activity. The audit, as an individual control, has been developing in the United States since the early 70's and at the end of the 80 's years of the XX century, some companies have reached a high, compared with the provided by the legislation, environmental indices. The active environmental audit, as well as environmental management, has begun to be implemented not only in the U.S. companies, but also was honored with a great trust in European companies. At present, environmental audit is actively introduced in the enterprises of Canada, Great Britain, Sweden and other countries. The leader in the development of environmental audit is the United Kingdom, where in 1992 the British Institute of Standardization has developed the standard of management of surrounding natural environment BS 7750 (Specification for Environmental Management System). Since the 80's of the last century, Europe adopted a system of ISO 14000 standards for environmental management and ISO 9000 for quality management, which in 1997 were approved to be the State standards of Ukraine and are the legal basis for the activities in the sphere of environmental audit. The need in the organization of environmental audit of the meliorated lands and watermelioration objects is substantiated by deterioration of the ecological conditions of irrigated, drained and adjacent lands, reduction in the volume of repair and reconstruction works on water economy facilities and hydrotechnical constructions, decompiling the lands of the meliorative fund, changing the ownership forms on agricultural land and water-melioration objects, transformation of the economic conditions in the country and in the system of the water economy. Environmental audit of water economy objects is a tool of management of anthropogenic economic activity with the aim of protection of the environment, increasing environmental safety and reduction of the risks probability as a result of economic activity and in the interests of sustainable development. The results of environmental audit are the basis for the development of directions and measures for the reconstruction and 
modernization of the infrastructure of the water industry and the restoration and expansion of irrigated areas with different technologies and ways of crops irrigation;

- Principle of financial and ecological balance. Reconstruction and modernization of the infrastructure of water industry can be carried out only if there is an investment, since this process is long-term, gradual and costly. Modernization is not just the replacement of the "old" infrastructure, it is a complex system of activities, for which it is necessary to define the specific directions and priorities. To ensure ecologically balanced and environmentally safe use of water it is necessary to carry out the reconstruction of irrigation canals, pumping stations, hydrotechnical constructions, sprinkler machinery and equipment. The methodology of estimation of the expenses for water supply for the needs of irrigation and drinking needs remains topical. Water tariffs should be calculated clearly with accordance to the expenses for water transportation and cost of water as a natural resource.

- Environmental management as a condition of providing environmentally-safe functioning of water economy in Ukraine. To implement an effective environmental management system in the water sector of the economy it is necessary to:

- Create the effective institutional infrastructure of environmental management taking into account the clear division of functions, rights and responsibilities of central, regional and local bodies of state and executive power in respect of water activities;

- Develop a stimulating tax system and benefits mechanism to ensure environmentally-safe and complex use of water resources;

- Form a flexible system of ecological insurance for water management objects with the aim of accumulation of financial funds for the elimination of losses that may be inflicted to the natural environment;

- Implement special regimes of an investment activity to stimulate investors, which comprehensively promote ecologization of water economy infrastructure and contribute to the introduction of environmentally-safe projects in the water economy;

- Improve the organizational and economic mechanism of introduction of the environmental management system in Ukraine, which is based on the development of methodology for the formation of environmental management; implementation of monitoring of current legislation in the system of water activities so that it could be improved.

Thus, ensuring the improvement of environmental quality should be the task of national value, and the main way of its solution is the state support, development and implementation of environmental quality management systems in accordance with the standards of DSTU ISO Series 9000 and 14000 , the principles of environmental initiatives recognized in Europe and 
in the world. In this respect, the aim of introduction of environmental management is to determine the strategic directions and priorities, environmental and economic foundations for the implementation of the State policy in water management, protection and reproduction. However, the mechanism for the introduction of environmental management is impossible without evaluation of the ecological and meliorative conditions of the irrigated and adjacent lands. This evaluation is provided by environmental monitoring, which is not currently perfect and requires development of directions and mechanisms for its improvement.

\section{Theoretical aspects of the development of environmental monitoring of agricultural lands in the zone of irrigation}

Agricultural land use is one of the main forms of negative impact on the environment. Ignoring the environmental principles of agricultural environmental use will inevitably accelerate the degradation and depletion of unique natural resources in southern region of Ukraine, reduce ecological and economic efficiency of agricultural production and, all in all, deepen the economic and socio-ecological problems of food security.

Ecologization of land use and limiting the negative impact of economic activity on the conditions of land and water resources in the zone of irrigation requires the formation of an effective system of ecological control, directed to checking the implementation of plans and measures for the rational nature and land conservation, compliance with the requirements of environmental legislation and environmental norms, especially in the zone of active development of irrigated agriculture. The decisive consideration in solving these tasks belongs to the introduction of an effective mechanism of environmental monitoring of agricultural land, which requires special attention in the context of transformation of the environmental legislation of Ukraine to the requirements of the European Union.

At the same time, there is a need to improve theoretical, methodical and scientific-practical foundations for the improvement of the environmental monitoring system of irrigated lands considering the existing legal and regulatory base, environmental limitations and incentives for rational nature.

Analysis of the existing situation in the agricultural land use in the zone of irrigation shows that irrigated land have been playing an important role in the food security of the country. This is due to the fact that a significant part of the country is allocated in the zone of insufficient and unstable humidification, and therefore, sustainable agriculture in these regions is possible only under the conditions of irrigation. Irrigated lands are an insurance foundation for sustainable agricultural production, especially in dry and extremely dry years. One of the key barriers to the reconstruction and further development of crops irrigation in Kherson region is the lack of an 
effective system of ecological monitoring of both irrigated and other agricultural lands, the result of which forms the base for the formation of systems of economic activity. The study of a change in the conditions of the irrigated soils after cessation of their irrigation is of a particular value because these lands are marked by the complex of negative processes, namely: secondary salinization and secondary alkalination of the soils. In addition, the irrigated lands have problems that are connected with the imperfect system of organization of agricultural production and land regulation, violation of the technological unity of the irrigated arrays, which is caused on the one hand, by distribution of the land between shareholders, and, as a consequence, by crushing and increasing the number of land users, and on the other hand by transfer of intra-economic systems in communal ownership and the balance of farmer and collective enterprises under the state ownership on the intereconomic network.

The structure of the monitoring system of the lands, soils and of the environmental monitoring of agricultural land in the zone of irrigation,its implementation is ineffective because the system uses parameters and indices that are not harmonized with the requirements of the European standards. Therefore, the issue of scientific substantiation of the directions for the improvement of environmental monitoring system as one of the functions of natural and environmental protection is closely linked to the features such as environmental expertise, environmental control and environmental audit.

As a result of scientific researches, a methodological approach to ecological and economic evaluation of agricultural land was developed on the basis of environmental monitoring as the basis for rehabilitation of agricultural lands by quantitative and qualitative parameters. Land use methodology is proposed to characterize the coefficient of ecological stability of the territory $\left(K_{\text {ec.st. }}\right)$, which further determines the land use structure ${ }^{8}$.

The scale of gradation of the ecological stability coefficient of a territory was developed on the basis of expert estimates: unstable territory $\left(K_{\text {ec.st. }}\right)<0.33$; seesaw stable $\left(K_{\text {ec.st. }}\right)$ varies within $0.34-0.50$; moderately stable $\left(K_{\text {ec.st. }}\right)-0.51-0.66$; stable $\left(K_{\text {ec.st. }}\right)>0.67$. The basis of the methodical approach is a theoretical approach to evaluating the level of environmental and economic efficiency of the use of agricultural landscapes of the south of Ukraine as a whole territorial system, which is described in the interregional aspect.

On the basis of the methodological approach integral evaluation of the irrigated agricultural lands was carried out, which includes criteria and indices according to the following groups: sanitary-hygienic state of soil, ecological

\footnotetext{
${ }^{8}$ Консервація деградованих, малопродуктивних і техногенно забруднених земель. Закон України «Про охорону земель». Стаття 172. Діє від 27.06.2015 p. URL: http://zakon3.rada.gov. ua/laws/show/962-15.
} 
resistance of soil, agrochemical parameters of soil fertility and hydrogeological-meliorative indices of land resources. The totality of these indices diagnoses the degree of environmental stability of different types of degradation processes in soils in the irrigated conditions. In this case, the integral evaluation is performed by the complex of indices that characterize the composition, properties, structure and condition of the main components of the ecosystem, the orientation and intensity of its transformation in the conditions of irrigation, the condition of water and soil pollution and other environmental changes. The integrated evaluation should be the basis for the conduction of natural-agricultural, eco-economic, anti-erosion and other types of zoning of the irrigated lands, the introduction of tools and levers of economic stimulation, rational use of soil protection technologies and increase in soil fertility (Fig. 1). The results of the study proved that the improvement of the existing monitoring system is possible only through the formation and introduction of the Unified State Ecological Monitoring System (USEMS) of a regional nature and defining the territorial subsystems in the formation of the regional environmental monitoring system.

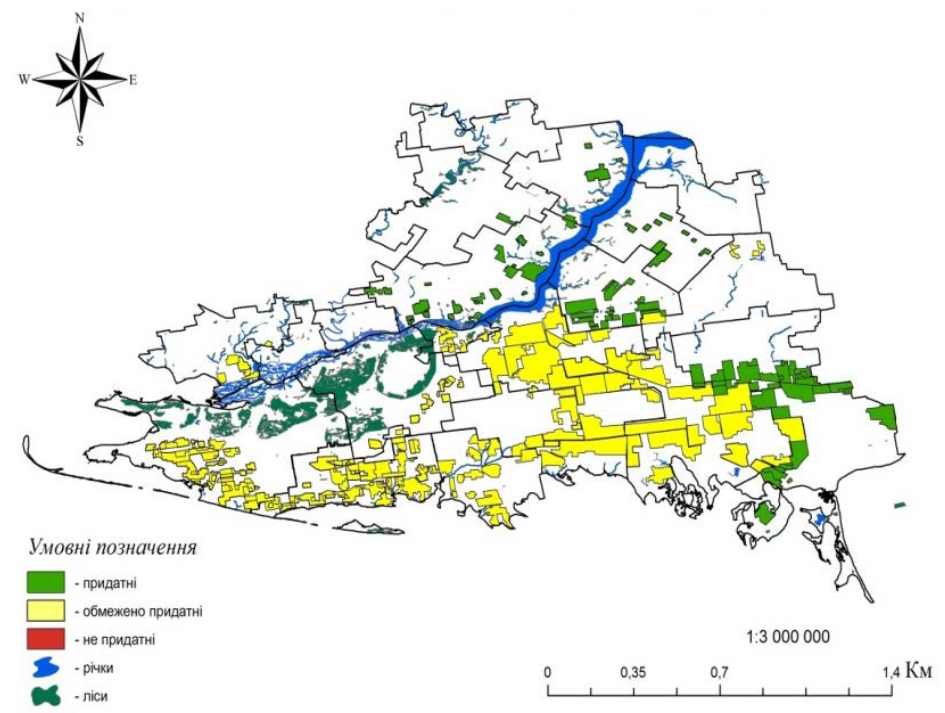

Fig. 1. Integral evaluation of suitability of the irrigated lands of Kherson region for cultivation ecologically safe agricultural products

In order to increase the level of ecological safety of epy irrigated agricultural land use a scientifically based scenario of ecologically-oriented systems of land use in the zone of irrigation were developed, namely: the use of the irrigated lands for cultivation ecologically safe products; the use of the 
irrigated lands in generally accepted zonal systems of irrigated agriculture; removing land from irrigation by conservation and separation of the arrays of the irrigated lands, which are in a degraded conditions.

The direction of processes, frequency and speed of transformation of soils under the influence of irrigation determine the quality of irrigation water, initial condition of soils, and degree of natural drainage of the territory, irrigation technology and usage intensity of the irrigated lands. Environmental monitoring of the irrigated lands provides a systematic evaluation of environmental situation, shows the area of the territory, which is under harmful phenomena, and the ability to develop proposals for the elimination of degradation processes (Fig. 2).

\begin{tabular}{|c|c|c|}
\hline \multicolumn{3}{|c|}{ Evolution of the irrigated soils } \\
\hline \multicolumn{2}{|r|}{$\downarrow$} & $\downarrow$ \\
\hline \multicolumn{2}{|c|}{$\begin{array}{l}\text { Irrigation with water of the first class, } \\
\text { automorphic and sub-automorphic conditions }\end{array}$} & $\begin{array}{c}\text { Irrigation with water } \\
\text { of } 2 \text { and } 3 \text { classes, } \\
\text { hygromorphic and sub- } \\
\text { hygromorphic conditions }\end{array}$ \\
\hline$\downarrow$ & $\downarrow$ & $\downarrow$ \\
\hline $\begin{array}{l}\text { High level } \\
\text { of agriculture }\end{array}$ & $\begin{array}{l}\text { Low level } \\
\text { of agriculture }\end{array}$ & $\begin{array}{c}\text { Development } \\
\text { of degradation processes: }\end{array}$ \\
\hline$\downarrow$ & $\downarrow$ & - raise of groundwater \\
\hline $\begin{array}{l}\text { Soil cultivation, } \\
\text { soil processes are } \\
\text { passing without } \\
\text { significant changes } \\
\text { in soil properties }\end{array}$ & $\begin{array}{l}\text { Development of soil } \\
\text { de-gradation } \\
\text { processes: } \\
\text { - dehumification; } \\
\text { - compaction; } \\
\text { - losing structure; } \\
\text { - alkalination, etc. }\end{array}$ & $\begin{array}{l}\text { level, flooding, } \\
\text { waterlogging; } \\
\text { - secondary salinization and } \\
\text { alkalination of soils; } \\
\text { - deterioration of } \\
\text { agrophysical properties of } \\
\text { soils; } \\
\text { - contamination of soils and } \\
\text { agricultural plants with } \\
\text { heavy metals, etc. }\end{array}$ \\
\hline
\end{tabular}

Fig. 2. Scheme of evolution of the irrigated soils

Choosing models of optimal development of environmental situations for further use of the irrigated lands is carried out by multifactor analysis of distributed in space and time information that describes the variability of sanitary and hygienic conditions of the soils (contamination by Cesium, Strontium, heavy metals, pesticides), indices of ecological stability of the soil (the content of humus in the arable layer, chemical reaction of the soil solution, bulk density, etc.), agro-chemical indices (the content of macro- and micro-elements) and hydrogeological-melìorative indices (quality of irrigation water, depth of occurrence and mineralization of groundwater, etc.). 
For each condition of the irrigated land there was developed a system of environmental measures directed on the prevention of the development of degradation processes in the conditions of irrigation, protection and reproduction of soil fertility and improved systematical complex of environmental standards of land use on the irrigated lands. Normative base of soil protection and rational use of land resources in the conditions of irrigation should be created on the hierarchical principle and include the following blocks: eco-technical and eco-technological norms; eco-economic and socioecological norms; safety standards ${ }^{9}$.

Organizational and economic mechanism of introduction of the environmental monitoring of agricultural land in the irrigation zone is carried out by the means of land policy: norms, standards, orders, recommendations and instructions. The normative base of soil protection and rational use of land resources in the conditions of irrigation in the system of environmental monitoring should be built on the hierarchical principle and include the following blocks: eco-technical and eco-technological norms; eco-economic and socio-ecological norms; protection standards; coordination of the development and execution of the programs of environmental monitoring; regulation and control of collection and processing of reliable and comparative data; storage of information, special data banks creation and maintenance and their harmonization (coordination, telecommunication) with international ecological and information systems; activity on the evaluation and prediction of environmental objects, natural resources, ecosystem reviews and public health under anthropogenic impact; availability of integrated environmental information for a wide range of consumers.

One of the measures that should be particularly pointed out due to its capacity to ensure the introduction of ecologically oriented systems of the land use on the basis of environmental monitoring in the conditions of irrigation is a withdrawal of land from irrigation ${ }^{10}$. Now this process takes place spontaneously, without complying with any rules and requirements. It often happens that irrigation is going on while it had to being stopped and, in contrary, irrigation is not carried out only because there is no technical means for this. One of the ways of rehabilitation of agricultural lands is their conservation - a withdrawal from the agricultural use for a certain period to carry out measures to restore their fertility. The priority of removal from agricultural use is subjected to low-productive and erosion-hazardous lands. Conservation of land is carried out by the means of turning them into grasslands or afforestation.

9 Земельний кодекс України від 25.10.2001 р. № 2768. Із змінами. Діє з 05.12.2013 p. http: // search.ligazakon.ua/I_doc2.nsf/link1/T012768.html.

10 Закон України «Про охорону земель». Діс від 27.06.2015 p. URL: http://zakon3.rada.gov.ua/ laws/show/962-15. 
It is possible to preserve both specific land plots and large land arrays. National and regional conservation programs for land can be developed to order interested executive authorities or local governments. After the coordination and approval of these programs by the relevant bodies of executive power or local self-government development of land conservation projects and their implementation are carried out within the respective administrative units (order of the State Committee of Ukraine on land resources from 17.10.2002 No. 175 "About the procedure of land conservation").

According to Art. 172 of the Law of Ukraine the conservation is subjected to degraded, low-productive and contaminated lands. The abovementioned points are almost literally reproduced in Art. 51 of the Law of Ukraine "About the protection of lands", they are detailed in the Order of the State Committee of Ukraine on land resources from 17.10.2002 No. 175 "About the procedure of land conservation". Legal concepts of technogenously contaminated lands are given in Art. 169, and of degraded and underproductive lands - in Article $171^{11}$.

The choice of conservation forms depends on the specific characteristics of the land plot. In particular, it is advisable to implement the afforestation in case of ravines, steep slopes, land plots along the roads, along the banks of reservoirs. It is advisable to turn the land plot into grassland before involvement of it in agricultural cultivation, etc.

According to the results of scientific researches it is possible to draw the conclusion that in order to improve the system of environmental monitoring of agricultural land, it is necessary to transform the existing legislation with accordance the requirements of the EU by introducing a unified state environmental monitoring system that should take into account the impact of irrigation and quality of irrigation water on soil conditions. It is necessary to add to the Land Code of Ukraine and the Law of Ukraine "About land reclamation"12 the point about giving the irrigated lands a special status, taking into account the personal responsibility of owners and tenants of such land for their intended use not only as agricultural, but also as irrigated lands and in order to stimulate their unification into holistic technological arrays.

\section{SUMMARY}

The article provides the principles of introduction of the system of environmental management, audit and monitoring in the water economy of Ukraine in order to ensure its ecologically safe functioning. Environmental audit and its results both for water economy and hydrotechnical objects and

\footnotetext{
${ }^{11}$ Концепція національної екологічної політики України на період до 2020 року. Діє від 17.10.2007 p. URL: http://zakon2.rada.gov.ua/laws/show/880-2007-\%D1\%80.

12 Закон України «Про меліорацію земель». Відомості Верховної Ради України (ВВР). 2000. № 11. Ст. 90. URL: https://zakon.rada.gov.ua/laws/show/1389-14.
} 
agricultural land are the basis for the introduction of engineering, melioration and environmental measures in the system of environmental management and audit. It is proved that the existing system of monitoring and environmental monitoring is the basis for the introduction of environmental management in the water economy of Ukraine and needs improvement. The proposals to extend the Land Code of Ukraine and the Law of Ukraine "About land reclamation" with new points in order to give the irrigated lands a special status taking into account the personal responsibility of owners and tenants of such land for their intended use are proved. Methodological approach to ecological and economic evaluation of agricultural land on the basis of environmental monitoring as a basis for the rehabilitation of agricultural lands for quantitative and qualitative indices was improved. In order to increase the level of environmental safety of the irrigated agricultural land use on the basis of the unified State system of ecological monitoring of irrigated land was developed and scientifically substantiated scenarios of ecological-oriented land use systems in the irrigation zone were proposed.

\section{REFERENCES}

1. Сербіна Р.А. Екологічне страхування меліорованих земель метод компенсації імовірності виникнення еколого-економічних ризиків. Економіка. Рівне, 2011. С. 40-46.

2. Ромащенко M.I. Концептуальні засади відновлення зрошення у Південному регіоні України. Меліорація і водне господарство. Київ, 2013. Вип. 100. С. 7-17.

3. Галушкіна Т.П., Грановська Л.М. Еколого-збалансовані пріоритети розвитку територій: концептуальні засади та організаційний механізм. Одеса: ІРРЕЕП, 2009. 372 с.

4. Про схвалення Стратегії розвитку аграрного сектору економіки на період до 2020 року. Кабінет Міністрів України; Розпорядження. Стратегія від 17.10.2013 № 806-р. Верховна рада України.

5. Програма економічних реформ Президента «Заможне суспільство, конкурентоспроможна економіка, ефективна держава». URL: http://www.president.gov.ua/docs/Programa_reform_FINAL_1.pdf.

6. Стратегія зрошення та дренажу в Україні на період до 2030 року. URL: https//zakon.rada.gov.ua/laws/688-2019-p/print

7. Закон України «Про державно-приватне партнерство». Відомості Верховної Ради України (ВВР), 2010. № 40. Ст. 524.

8. Консервація деградованих, малопродуктивних і техногенно забруднених земель. Закон України «Про охорону земель». Стаття 172. Діє від 27.06.2015 p. URL: http://zakon3.rada.gov.ua/laws/show/962-15.

9. Земельний кодекс України від 25.10.2001р. № 2768. Із змінами. Дiє 3 05.12.2013 p. URL: http: // search.ligazakon.ua/I_doc2.nsf/link1/ T012768.html. 
10. Закон України «Про охорону земель». Діє від 27.06.2015 р. URL: http://zakon3.rada.gov.ua/laws/show/962-15.

11. Концепція національної екологічної політики України на період до 2020 року. Діє від 17.10.2007 p. URL: http://zakon2.rada.gov.ua/ laws/show/880-2007-\%D1\%80.

12. Закон України «Про меліорацію земель». Відомості Верховної Ради України (BВP). 2000. № 11. Ст. 90. URL: https://zakon.rada.gov.ua/ laws/show/1389-14.

\section{Information about the author:}

Hranovska L. M.,

Doctor of Economics Sciences, Professor, Institute of Irrigated Agriculture of the National Academy of Agrarian Sciences of Ukraine Kherson, Naddnipryanske, 73483, Ukraine 